\title{
Density of pack-ice seals and penguins in the western Weddell Sea in relation to ice thickness and ocean depth
}

\author{
Hauke Flores $^{\mathrm{a}, *}$, Christian Haas ${ }^{\mathrm{b}, 1}$, Jan Andries van Franeker ${ }^{\mathrm{a}}$, Erik Meesters ${ }^{\mathrm{a}}$ \\ ${ }^{a}$ Wageningen IMARES, P.O. Box 167, 1790 AD Den Burg, The Netherlands \\ ${ }^{\mathrm{b}}$ Alfred Wegener Institute for Polar and Marine Research, Bremerhaven, Germany
}

Accepted 27 December 2007

Available online 15 April 2008

\begin{abstract}
Aerial band transect censuses were carried out parallel with ice thickness profiling surveys in the pack ice of the western Weddell Sea during the ISPOL (Ice Station POLarstern) expedition of R.V. Polarstern from November 2004 to January 2005. Three regions were surveyed: the deep sea of the Weddell Sea, a western continental shelf/slope region where R.V. Polarstern passively drifted with an ice floe (ISPOL), and a northern region (N). Animal densities were compared among regions and in relation to bathymetry and ice thickness distribution. Crabeater seals Lobodon carcinophaga were the most abundant species in all three regions. Their density was significantly lower in the deep sea $\left(0.50 \mathrm{~km}^{-2}\right)$ than in the ISPOL $\left(1.00 \mathrm{~km}^{-2}\right)$ and northern regions $\left(1.21 \mathrm{~km}^{-2}\right)$. Weddell seals Leptonychotes weddellii were not sighted in the deep-sea region, their density elsewhere ranging from $0.03(\mathrm{~N})$ to $0.08 \mathrm{~km}^{-2}$ (ISPOL). Leopard seals Hydrurga leptonyx were observed in all three areas, but could only be quantified in the deep-sea $\left(0.05 \mathrm{~km}^{-2}\right)$ and northern regions $\left(0.06 \mathrm{~km}^{-2}\right)$. The abundance of emperor penguins Aptenodytes forsteri was markedly higher in the northern $\left(0.75 \mathrm{~km}^{-2}\right)$ than in the ISPOL $\left(0.13 \mathrm{~km}^{-2}\right)$ and the deep-sea region (not quantified). Crabeater seal density was significantly related to ocean depth and modal ice thickness.
\end{abstract}

(C) 2008 Elsevier Ltd. All rights reserved.

Keywords: Aerial surveys; Antarctic seals; Distribution; Lobodon carcinophaga; Penguins; Sea ice; Weddell Sea; $66^{\circ} \mathrm{S} 58^{\circ} \mathrm{W} / 69^{\circ} \mathrm{S} 38^{\circ} \mathrm{W}$

\section{Introduction}

In the Southern Ocean, sea ice is a major factor controlling the distribution of birds and mammals (Ainley et al., 1994, 1998; Van Franeker et al., 1997; Southwell et al., 2005). For many top predators, ice provides a foraging ground, resting site and nursery platform. Changes in the extent of sea ice are thus bound to affect populations of those species (Croxall et al., 2002; Weimerskirch et al., 2003). In the Weddell Sea the distribution of pack ice is largely controlled by the Weddell Gyre (Orsi et al., 1993; Yaremchuk et al., 1998). Its clockwise transport of surface water enhances the retention of sea ice in the southern and western Weddell Sea, making it a region where significant

\footnotetext{
*Corresponding author. Tel: +31222 369 768; fax: + 31222319235 .

E-mail address: hauke.flores@wur.nl (H. Flores).

${ }^{1}$ Now at Department of Earth \& Atmospheric Sciences at University of Alberta, Edmonton, Canada.
}

amounts of oceanic multi-year ice persist through summer (Gill, 1973; Harder and Fischer, 1999).

Various characteristics of sea ice, including ice cover, floe size, age and structure, are closely related to ice thickness distribution. Satellite imagery does not provide sufficient small-scale detail on ice thickness, but a new method using airborne electromagnetic induction can provide highresolution data (Haas et al., 2007a, b).

A number of bird and mammal species have developed a mode of life entirely adapted to the Antarctic pack ice. Four ice-breeding seal species are found in the Antarctic. Among them, the crabeater seal Lobodon carcinophaga is the most abundant (Erickson and Hanson, 1990). During the breeding period, which lasts from September to early November (Siniff, 1991; Southwell et al., 2003), its distribution may be controlled by ocean depth and seaice distribution (Southwell et al., 2005). The leopard seal Hydrurga leptonyx is less abundant but disperses more widely (Bester et al., 1995, 2002). Mother-pup pairs were observed on sea ice between early November and late 
December (Southwell et al., 2003). The Weddell seal Leptonychotes weddellii contrasts with the previous two species by being largely confined to coastal shelf areas (Siniff, 1991), breeding on fast ice between October and December (Reijnders et al., 1990; Lake et al., 1997; Southwell et al., 2003). The Ross seal Ommatophoca rossii is the least abundant species of ice seals, breeding on sea ice in the period from late October to late November (Southwell et al., 2003).

Among the penguins, only two species are fully adapted to life in ice-covered waters. The emperor penguin Aptenodytes forsteri even breeds on coastal fast ice during the winter period (Woehler, 1993; Kooyman, 2002). The Adélie penguin Pygoscelis adeliae breeds during summer in colonies on ice-free parts of the continental coast or nearby islands (Woehler, 1993; Kerry et al., 1995; Kirkwood and Robertson, 1997). The Chinstrap Penguin Pygoscelis antarctica is an ice species to some extent, but is restricted to more northerly areas, barely reaching the outer edge of the pack ice (Kooyman, 2002).

There is little recent information on top predator abundance in the inner Weddell Sea. A number of attempts were made to quantify seal abundance, dating from more than 20 years ago (Bonner and Laws, 1964; Siniff et al., 1970; Erickson et al., 1983). The latest report gathers data mainly collected in the eastern Weddell Sea, where pack ice was virtually absent during the survey (Bester and Odendaal, 2000). Other more recent top predator censuses concentrated on the more northern Weddell Sea pack ice and adjacent open water (Joiris, 1991; Van Franeker, 1992), the Lazarev Sea (Bester et al., 1995, 2002), east Antarctica (McMahon et al., 2002; Southwell et al., 2005) and the Ross Sea (Ainley et al., 1984; Van Dam and Kooyman, 2003).

Several publications have attempted to link top predator density to ice properties, mostly focusing on 'horizontal' properties, such as proportion of ice cover, floe size or ice type (Van Franeker et al., 1997; Bester et al., 2002; Chapman et al., 2004; Southwell et al., 2005). Only McMahon et al. (2002) included ice thickness as a variable tested to predict the distribution of crabeater seals in winter.

During the ISPOL 2004/2005 expedition, aerial ice thickness profiling surveys offered the opportunity to combine top predator censuses with on-line ice thickness measurements. This paper provides new information on the distribution and abundance of penguins and seals in the pack ice of the western Weddell Sea and discusses potential correlations of crabeater seal density with ice thickness and bathymetry.

\section{Methods}

\subsection{Data collection}

Aerial surveys of top predators and ice thickness measurements were conducted simultaneously from a BO
105 helicopter between 20 November 2004 and 4 January 2005 during the Ice Station POLarstern (ISPOL) cruise of R.V. Polarstern (ANT XXII-2).

Ice thickness was measured with a helicopter-borne electro-magnetic induction sensor, the so-called EM-Bird. Ice thickness was obtained as an estimate of total ice (plus snow) thickness with an accuracy of $\pm 0.1 \mathrm{~m}$ over level ice and with a spacing of $3-4 \mathrm{~m}$ between measurements. For further details on the accuracy and processing of EM measurements, see Haas et al. (2007a, b) and Pfaffling et al. (2007).

Censuses of top predators were conducted by a single observer (H. Flores) during flights made for ice thickness distribution mapping. Some aspects of census methods were imposed by requirements for the ice study. Most importantly, flight altitude for ice measurements was generally fixed at $\pm 30 \mathrm{~m}$, which is well below the altitude commonly used in aerial surveys of pack-ice seals (Bester and Odendaal, 2000; Bester et al., 2002; Southwell, 2005b). Standard flight speed during the surveys was \pm 80 knots $\left( \pm 148 \mathrm{~km} \mathrm{~h}^{-1}\right)$.

Census methodology followed a band transect procedure (e.g., Wiig and Derocher, 1999). Because of the low altitude and relatively high speed of the helicopter, a very narrow transect width had to be used to meet the prerequisite of detection of all animals present within the band. Reference points inside the cockpit were used to identify the borders of the transect band. The cockpit reference points were constructed using markings on the heli-deck viewed by the observer in a fixed position. Distances between markings on deck were extrapolated to bandwidth at ground level when flying at standard altitude. Depending on the actual flight altitude, the width of the transect band at ground level varied from 70 to $80 \mathrm{~m}$. Correctness of the reference points in identifying band width at ground level was controlled by flying over an object of known length (the Polarstern) at survey altitude.

Flights were conducted in three different regions (Fig. 1; Table 1):

(1) the deep-sea part of the Weddell Sea with ocean depth exceeding $2000 \mathrm{~m}$ (DS);

(2) the region around ISPOL where Polarstern was anchored to an ice floe and drifted along the western shelf-slope of the Weddell Sea (ISPOL);

(3) a region along the ship's northbound track after leaving the floe $(\mathrm{N})$.

Flight tracks were designed as either two parallel transects (DS) or in a triangular pattern (ISPOL, N), in which case each side of the triangle was considered as a transect. Ice thickness measurements were made during all flights in the deep-sea and ISPOL areas, but not in the northern region. One northern flight was made exclusively for the predator survey, during which flight altitude was changed to $60 \mathrm{~m}$, widening the transect band to $140 \mathrm{~m}$. Ocean depth at the geographic centre point 


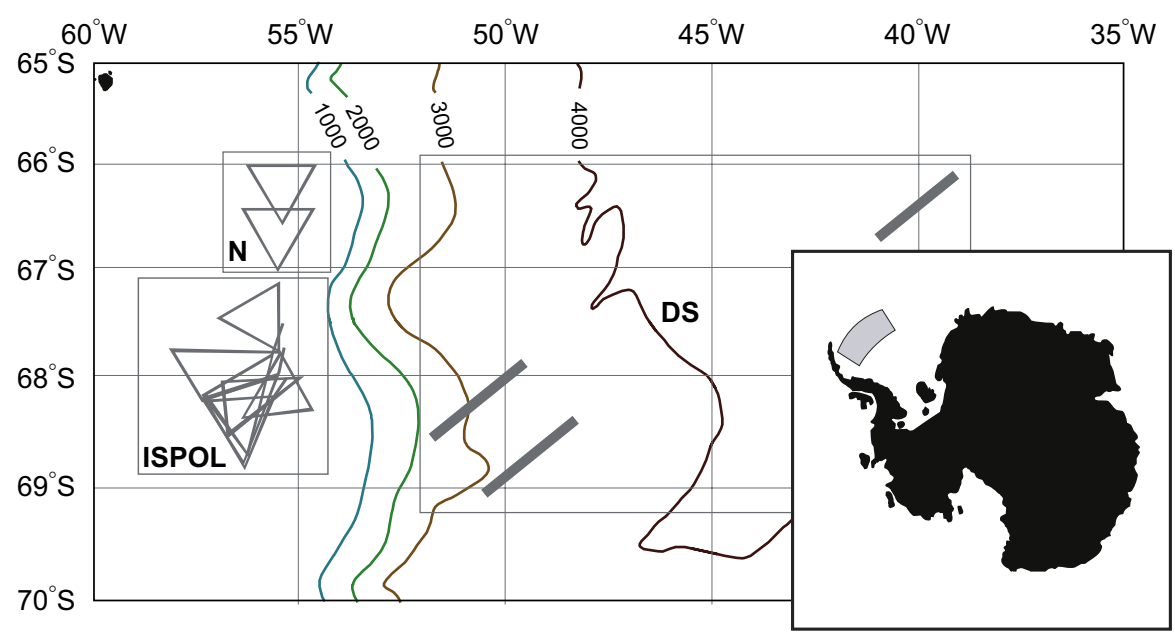

Fig. 1. Distribution of census flights in the western Weddell Sea. Flight patterns in indicated survey regions drawn in grey. DS $=$ deep sea region; $\mathrm{ISPOL}=\mathrm{ISPOL}$ floe region; $\mathrm{N}=$ northern region. Solid lines represent $1000 \mathrm{~m}$ isobaths. Geographic overview in lower right corner.

Table 1

List of census flights

\begin{tabular}{|c|c|c|c|c|c|c|}
\hline Region & Flight date & Hour of day & Depth (m) & No. of transects & Transect width (m) & Area $\left(\mathrm{km}^{2}\right)$ \\
\hline \multirow[t]{3}{*}{ Deep sea (DS) } & 20 Nov 2004 & $12-14$ & 4644 & 2 & 70 & 9.6 \\
\hline & 22 Nov 2004 & $13-14$ & 3378 & 2 & 70 & 11.0 \\
\hline & 24 Nov 2004 & $10-12$ & 3280 & 2 & 70 & 11.9 \\
\hline DS total & & & & 6 & & 32.5 \\
\hline \multirow[t]{7}{*}{ ISPOL } & 29 Nov 2004 & $8-9$ & 1006 & 3 & 70 & 10.4 \\
\hline & 9 Dec 2004 & $5-7$ & 601 & 3 & 80 & 17.6 \\
\hline & 14 Dec 2004 & $5-7$ & 1328 & 3 & 75 & 14.7 \\
\hline & 14 Dec 2004 & $8-9$ & 629 & 3 & 75 & 15.7 \\
\hline & 15 Dec 2004 & $10-12$ & 458 & 3 & 75 & 17.8 \\
\hline & 18 Dec 2004 & $6-8$ & 539 & 3 & 70 & 18.4 \\
\hline & 29 Dec 2004 & $10-12$ & 492 & 4 & 70 & 20.1 \\
\hline ISPOL total & & & & 22 & & 114.7 \\
\hline \multirow[t]{2}{*}{ North (N) } & 03 Jan 2005 & $11-13$ & 1211 & 3 & 140 & 31.7 \\
\hline & 04 Jan 2005 & $8-9$ & 698 & 3 & 70 & 12.1 \\
\hline $\mathrm{N}$ total & & & & 6 & & 43.8 \\
\hline All regions & & & & 34 & & 190.9 \\
\hline
\end{tabular}

Hour of day in approximate solar time. Flights without parallel ice thickness measurements in italics.

of each transect was estimated with bathymetric data based on combined depth soundings and satellite-based gravity measurements from a public database (Smith and Sandwell, 1997; Scripps Oceanographic Institution, 2006).

Seals and penguins were identified to species if possible, and counted. Animals sighted outside the transect band also were noted in order to collect qualitative distributional data on less common species. Each sighting was assigned a GPS waypoint to record time and position along the transect line. The census was continuous during the time the helicopter was moving along the transect at standard altitude and speed. Counting was paused when passing corner points of triangular flights to avoid repeated counts of the same animals.

\subsection{Data analysis}

For all ice thickness measurement flights, average, mode, minimum, maximum and coefficient of variance of ice thickness were calculated per transect. We computed the percentages of younger first-year (thickness $0.20-1.49 \mathrm{~m}$ ), older first-year $(1.50-2.19 \mathrm{~m})$, second-year $(2.20-3.49 \mathrm{~m})$ and ridged ice $(>3.50 \mathrm{~m})$. Newly formed ice was not observed during the surveys. Measurements of ice thickness $<0.20 \mathrm{~m}$ were considered open water.

The density of penguins and seals was calculated per species for each transect, and the average transect densities were calculated for each region.

The relationship of the density of crabeater seals with bathymetry and ice characteristics in the deep-sea and 
ISPOL regions was explored with Generalised Linear Models (GLM: McCullagh and Nelder, 1989). We used a Poisson error distribution with a correction for overdispersion (in $\mathrm{R}$ termed quasipoisson) combined with a log-link function. Seal densities were transformed to numbers per $10 \mathrm{~km}^{2}$ in order to obtain discrete values necessary for the assumed Poisson distribution of the model. Depth data were log-transformed. Variables were tested for collinearity using variance inflation factors (VIF). A VIF value of 10 is often suggested as proof of strong collinearity (Quinn and Keough, 2004). In the selection procedure, the variable with the highest VIF value was removed and calculations repeated untill all variables had VIF values below 10. After exclusion of variables with VIF $>10$, high values remained for the variables percentage open water (9.9) and maximum ice thickness (9.2). Exclusion of these two variables lowered VIF values of the remaining set below 2.5. For the regression we selected this set of variables including $\log ($ depth), modal ice thickness, minimum ice thickness, coefficient of variance of ice thickness, percentage young first-year ice and percentage old-first-year ice. During the model selection process variables were eliminated by a best subset regression using a stepwise forward and backward procedure, and the best model was estimated based on the lowest Akaike Information Criterion. Regression assumptions were assessed visually by plotting residuals against variables and fitted values. Statistical analyses were performed using the R ( R Development Core Team, 2006) and Brodgar (Highland Statistics, 2006) software packages.

\section{Results}

Between 20 November 2004 and 4 January 2005, 34 transects were completed over a total linear distance of $2410.5 \mathrm{~km}$, totalling to a surveyed area of $190.9 \mathrm{~km}^{2}$ (Fig. 1; Table 1). All deep sea and ISPOL transects were over dense pack ice, with ice concentrations between $90 \%$ and $100 \%$ (Table 2). Ice thickness could not be measured in the

Table 2

Averages $( \pm$ SE) of ice thickness characteristics in the deep sea and ISPOL regions

\begin{tabular}{lrc}
\hline & Deep sea & \multicolumn{1}{c}{ ISPOL } \\
\hline Area surveyed $\left(\mathrm{km}^{2}\right)$ & \multicolumn{1}{c}{32.5} & 114.7 \\
Modal thickness $(\mathrm{m})$ & $0.6^{*} \pm 0.4$ & $1.9 \pm 0.2$ \\
Average thickness $(\mathrm{m})$ & $2.1^{* *} \pm 0.2$ & $2.9 \pm 0.1$ \\
Open water $(\%)$ & $9.6^{* *} \pm 2.0$ & $3.1 \pm 0.5$ \\
Young first-year $(\%)(20-149 \mathrm{~cm})$ & $27.9^{* *} \pm 7.5$ & $6.8 \pm 0.7$ \\
Old first-year $(\%)(150-219 \mathrm{~cm})$ & $20.2 \pm 2.2$ & $22.1 \pm 1.5$ \\
Second-year $(\%)(220-349 \mathrm{~cm})$ & $28.0^{*} \pm 4.7$ & $40.2 \pm 1.2$ \\
Ridged $(\%)(\geqslant 350 \mathrm{~cm})$ & $14.4^{* *} \pm 3.0$ & $27.8 \pm 2.4$ \\
\hline
\end{tabular}

No measurements were obtained in the northern region. Marked values significantly different from other region (Mann-Whitney $U$-test).

${ }^{*} P<0.05$.

$* * P<0.01$. northern region. The ice edge as estimated from shipboard observations was situated at a distance of $\pm 110 \mathrm{~km}$ from the northern edge of the northernmost survey, at approximately $65^{\circ} 33^{\prime} \mathrm{S}$.

The ice was significantly thicker and the proportion of open water was lower in the ISPOL than in the deep-sea region (Table 2). This observation was reflected by the thickness distribution with a significantly higher proportion of second-year ice, a lower percentage of young firstyear ice and a larger amount of ridged ice in the ISPOL region (Haas et al., 2007a, b; Hellmer et al., 2006). Firstyear ice floes were covered with $0.2-0.4 \mathrm{~m}$ of snow, and second-year floes by $0.6-1.0 \mathrm{~m}$. The snow layer is included in the ice thickness estimates in Table 2.

A total of 211 seals were counted within the band transects: 194 crabeater, 4 leopard, 11 Weddell, and 2 unidentified seals. Seals sighted outside the transect band included 390 crabeater, 7 leopard, 10 Weddell and 53 unidentified seals. No Ross seals were observed. A total of 44 emperor penguins was counted within the transect band. Penguins sighted outside the transect band included 86 emperor penguins, one Adélie penguin and eleven unidentified penguins.

Densities of seals and penguins are listed in Table 3. The density of crabeater seals in the deep-sea region was significantly lower than in the two shallower western areas. The density of emperor penguins in the northern region was almost an order of magnitude higher than in the ISPOL and deep-sea regions. Low sighting frequencies of Weddell and leopard seals prevent meaningful density comparisons. Weddell seals were not sighted at all (in or out of transect) in the deep-sea region.

Results of the GLM analysis applied to investigate the relationship of crabeater seal density with ice characteristics and ocean depth are provided in Table 4 . The best model (model 1) included ocean depth, modal ice thickness and the coefficient of variance of ice thickness (CV). However, the regression coefficient for $\mathrm{CV}$ was not significant and model performance was not significantly

Table 3

Mean densities $( \pm$ SE) of seals and penguins on pack ice in different regions of the Weddell Sea

\begin{tabular}{llll}
\hline & Deep sea & ISPOL & North \\
\hline Area surveyed $\left(\mathrm{km}^{2}\right)$ & 32.5 & 114.7 & 43.8 \\
Crabeater seal $(n=194)$ & $0.50^{*} \pm 0.14$ & $1.00 \pm 0.13$ & $1.21 \pm 0.16$ \\
Weddell seal $(n=11)$ & - & $0.08 \pm 0.06$ & $0.03 \pm 0.02$ \\
Leopard seal $(n=4)$ & $0.05 \pm 0.05$ & + & $0.06 \pm 0.04$ \\
Unid. seal $(n=2)$ & $0.06 \pm 0.04$ & + & + \\
Emperor penguin $(n=44)$ & + & $0.13^{* *} \pm 0.05$ & $0.75 \pm 0.25$ \\
Adélie penguin & - & - & + \\
Unid. Penguin & - & + & + \\
\hline
\end{tabular}

$-=$ species not sighted; $+=$ species sighted but not present inside transect bands. $n$ : number of sightings in transect band. Marked values significantly different from all other regions (Mann-Whitney $U$-test).

${ }^{*} P<0.05$.

${ }^{* *} P<0.01$. 
Table 4

Coefficients for generalised linear models on crabeater seal density and environmental variables

\begin{tabular}{lllllll}
\hline Model & Rdev & Intercept & $\log (D)$ & CV & MTH & AIC \\
\hline 1 & 106.17 & $6.64^{* *}$ & $-1.09^{*}$ & 0.95 & $-0.33^{*}$ & 241.02 \\
2 & 115.48 & $6.44^{* *}$ & $-1.26^{* *}$ & - & $-0.31^{*}$ & 242.66 \\
\hline
\end{tabular}

Model 1 is the best model with lowest AIC. Model 2 the most parsimonious model. AIC = akaike information criterion; $\mathrm{CV}=$ coefficient of variation of ice thickness; $D=$ depth; $\mathrm{MTH}=$ modal ice thickness; Rdev = residual deviance. Significance:

$* P<0.05$.

** $P<0.01$.

better after removal of CV ( $F$-test: $F_{24,25}=2.69, P=0.11$ ). Consequently, model 2 , including depth and modal ice thickness was chosen as the most parsimonious model to describe crabeater seal density.

\section{Discussion}

\subsection{Abundance and distribution}

Among the 211 seals seen inside the transect band, 92\% were crabeater, $2 \%$ leopard, $0 \%$ Ross, $5 \%$ Weddell and $1 \%$ unidentified seals. Bester and Odendaal (2000) found those proportions in the Weddell Sea to be $91 \%$ crabeater, $1 \%$ leopard, $0.3 \%$ Ross, $2 \%$ Weddell and $6 \%$ unidentified seals. Overall density estimates for Antarctic pack-ice seals reported by Erickson and Hanson (1990) work out to 89\% crabeater, 4\% Leopard, 2\% Ross and 5\% Weddell seals. Thus, the proportional abundance of seal species encountered on the ISPOL 2004/2005 helicopter surveys compares well with that of other studies. The limited survey area reduced detectability of low abundance species in some or all regions, such as Ross seals in general and Weddell seals in the deep-sea region (Table 3).

The overall density of crabeater seals in our study was $1.02 \mathrm{~km}^{-2}$ (194 seals in $190.9 \mathrm{~km}^{2}$ ) with regional averages ranging from 0.50 to $1.21 \mathrm{~km}^{-2}$. Such densities in the Weddell Sea pack-ice are within the range reported for the Weddell Sea in studies conducted farther to the north (Joiris, 1991; Van Franeker, 1992) and to the east (Bester et al., 1995, 2002). Only Bester and Odendaal (2000) found a considerably higher crabeater seal density of $8.01 \mathrm{~km}^{-2}$, which was considered an exceptional concentration in a small residual ice area in late summer. Observed densities of leopard and Weddell seals in our study were similar to those reported for nearby areas (Erickson and Hanson, 1990; Joiris, 1991; Van Franeker, 1992).

Densities of crabeater seals in the westerly ISPOL and northern regions were significantly higher than in the more eastern deep-sea area (Table 3). Erickson et al. (1983) made an analogous observation over a similar longitudinal range further north, observing a decline in crabeater seal density from $2.74 \mathrm{~km}^{-2}$ in shelf and slope areas to $0.41 \mathrm{~km}^{-2}$ over eastern deeper waters.
Van Franeker (1992) made north-south transects in the western Weddell Sea south to $62^{\circ} \mathrm{S}$ and indicated that seal densities remained high irrespective of distance from the ice edge. Our current observations confirm that statement for pack ice south to $69^{\circ} \mathrm{S}$, further indicating that high food availability under ice is not limited to an enriched marginal ice zone, but persists throughout the closed pack ice.

Crabeater seals are known to have synchronized haulout patterns that vary with season and time of day. Southwell (2005a) found that a stable proportion of approximately $80 \%$ of crabeater seals hauled out on ice during most of the daylight period (from $\pm 07: 00$ to 17:00 h) in the postpupping season (after 30 November). Based on a smaller sample size, Bengtson and Cameron (2004) estimated the proportion of crabeater seals hauling out at maximum $65 \%$ in December, and for a shorter daylight period. A tentative correction for haulout behaviour of crabeater seals would increase the uncorrected overall density of $1.02 \mathrm{~km}^{-2}$ to a corrected density in the range of 1.28 (according to Southwell, 2005a) to $1.57 \mathrm{~km}^{-2}$ (according to Bengtson and Cameron, 2004).

Emperor penguins were significantly more abundant in the northern region than in the other two regions, also exceeding densities of emperor penguins found in the pack ice as reported by e.g. Ainley et al. (1984); Joiris (1991) and Woehler (1997). The locally elevated density of emperor penguins is consistent with the recent discovery of a nearby colony of this species on fast ice close to Snow Hill Island $64^{\circ} 32^{\prime} \mathrm{S}, 57^{\circ} 26^{\prime} \mathrm{W}$ (Coria and Montalti, 2000).

Only one Adélie penguin was observed outside the transect band during the helicopter surveys. Also from the ship, at stations and during sailing, the species was only sighted infrequently. Apparently, Adélie penguins breeding around the tip of the Antarctic Peninsula and South Orkney Islands do not forage this far south during the breeding season. The closest breeding colonies reported by Woehler (1993) are situated at approximately $64^{\circ} \mathrm{S} 57^{\circ}$ west, two to five degrees of latitude $(220-560 \mathrm{~km})$ north of the area surveyed in this study. Closer to those breeding locations, Joiris (1991) and Van Franeker (1992) observed considerable densities of Adélie penguins. In the vicinity of these breeding areas, chinstrap penguins also can be seen in the pack ice, inspite of their preference for more openwater situations in the marginal ice zone and more northerly waters. No chinstrap penguins at all were encountered in our study area.

\subsection{Crabeater seal density in relation to ice characteristics and ocean depth}

A negative relation of crabeater seal distribution with both ice thickness and ocean depth was apparent from our model. Crabeater seal abundance has been reported to correlate with sea-ice concentration (Van Franeker, 1992; Bester et al., 2002). In our study, however, sea-ice concentration (inversely expressed as the percentage of open water) was excluded in the model selection process 
because of high variance inflation in combination with the other variables. Similar to McMahon et al. (2002), ocean depth and ice thickness were identified as the only two factors related to crabeater seal density. Our results show a slightly negative relationship between modal ice thickness and seal density, whereas McMahon et al. (2002) found the opposite trend. This disagreement most likely can be explained by the absence of new ice $(<20 \mathrm{~cm})$ from our dataset. In our model calculations, thin ice unsuitable for haulout would contribute to a positive relationship of seal density and ice thickness. The pattern observed in our study appears to be typical for the high end of the ice thickness range, where thick, ridged ice seems less attractive for seals.

The negative relationship of ocean depth with crabeater seal density from our model agrees with the model of McMahon et al. (2002). A similar correlation also was found by Chapman et al. (2004), who did not include ice thickness in their model. Concentrations of top predators are often associated with shelf and slope areas such as the ISPOL and northern regions, where local hydrographical patterns may enhance primary production, supporting an enriched food web up to the level of top predators (Ainley et al., 1998; Tynan, 1998).

\section{Conclusions}

The present study adds new data on the summer density of pack-ice seals and penguins in the rarely surveyed inner pack ice of the western Weddell Sea. Results show that the inner pack ice is as important for crabeater seal populations as the marginal ice zone. This study is the first combining animal censuses with continuous ice thickness measurements, showing the relation between density of crabeater seals, ocean depth and ice thickness. In spite of limitations in spatial coverage and methodology, the applicability of this combined approach could be demonstrated.

\section{Acknowledgements}

We are grateful for the support received from the crew of the R.V. Polarstern ANT XXII-2 (ISPOL) expedition, J. Büchner and M. Federowitz from Heli Transair and I. Nunez-Riboni (AWI). We thank the reviewers M.N. Bester and J. Plötz for their contribution to the improvement of this publication. This project was funded by the Netherlands Organisation for Scientific Research (NWO), the Netherlands Polar Programme (NPP) and the Netherlands Ministry for Agriculture, Nature and Food Quality (LNV).

\section{References}

Ainley, D.G., O'Connor, E.F., Boekelheide, R.J., 1984. The marine ecology of birds in the Ross Sea, Antarctica. Ornithological Monographs $32,1-97$.
Ainley, D.G., Ribic, C.A., Fraser, W.R., 1994. Ecological structure among migrant and resident seabirds of the Scotia-Weddell confluence region. Journal of Animal Ecology 63, 247-364.

Ainley, D.G., Jacobs, S.S., Ribic, C.A., Gaffney, I., 1998. Seabird distribution and oceanic features of the Amundsen and southern Bellingshausen seas. Antarctic Science 10, 111-123.

Bengtson, J.L., Cameron, M.F., 2004. Seasonal haulout patterns of crabeater seals (Lobodon carcinophaga). Polar Biology 27, 344-349.

Bester, M.N., Odendaal, P.N., 2000. Abundance and distribution of Antarctic pack ice seals in the Weddell Sea. In: Davison, W., Howard-Williams, C. (Eds.), Antarctic Ecosystems: Models for Wider Ecological Understanding. Caxton Press, Christchurch, pp. 51-55.

Bester, M.N., Erickson, A.W., Ferguson, J.W.H., 1995. Seasonal change in the distribution and density of seals in the pack ice off Princess Martha Coast, Antarctica. Antarctic Science 7, 357-364.

Bester, M.N., Ferguson, J.W.H., Jonker, F.C., 2002. Population densities of pack ice seals in the Lazarev Sea, Antarctica. Antarctic Science 14, 123-127.

Bonner, W.N., Laws, R.M., 1964. Seals and sealing. In: Priestley, R., Adie, J.R., Robin, G.d.Q. (Eds.), Antarctic Research. Butterworths, London, pp. 163-190.

Chapman, E.W., Ribic, C.A., Fraser, W.R., 2004. The distribution of seabirds and pinnipeds in Marguerite Bay and their relationship to physical features during austral winter 2001. Deep-Sea Research II 51, 2261-2278.

Coria, N.R., Montalti, D., 2000. A newly discovered breeding colony of Emperor Penguins Aptenodytes forsteri. Marine Ornithology 28, $119-120$.

Croxall, J.P., Trathan, P.N., Murphy, E.J., 2002. Environmental change and Antarctic seabird populations. Science 297, 1510-1514.

Erickson, A.W., Hanson, M.B., 1990. Continental estimates and population trends of Antarctic ice seals. In: Kerry, K.R., Hempel, G. (Eds.), Antarctic Ecosystems. Ecological Change and Conservation. Springer, Berlin, Heidelberg, New York, pp. 253-264.

Erickson, A.W., Hanson, M.B., Kehoe, D.M., 1983. Population densities of seals and whales observed during the 1983 circumnavigation of Antarctica by the USCGC POLAR STAR. Antarctic Journal of the US 18, 163-166.

Gill, A.E., 1973. Circulation and bottom water production in Weddell Sea. Deep-Sea Research 20, 111-140.

Haas, C., Hendricks, S., Doble, M., 2007a. Comparison of the sea ice thickness distribution in the Lincoln Sea and adjacent Arctic Ocean in 2004 and 2005. Annals of Glaciology 44, 247-252.

Haas, C., Nikolaus, M., Batzke, A., Willmes, S., Lobach, J., $2007 \mathrm{~b}$. Changes in sea ice physical properties during the onset of melt. In: El Naggar, S., Dieckmann, G., Haas, C., Schröder, M., Spindler, M. (Eds.), The Expeditions ANTARKTIS-XXII/1 and XXII/2 of the Research Vessel "Polarstern" in 2004/2005. Reports on Polar and Marine Research 551, pp. 71-102.

Harder, M., Fischer, H., 1999. Sea ice dynamics in the Weddell Sea simulated with an optimized model. Journal of Geophysical Research-Oceans 104, 11151-11162.

Hellmer, H., Haas, C., Dieckmann, G.S., Schröder, M., 2006. Sea ice feedbacks observed in western Weddell Sea. EOS Transactions 87, 173-179.

Highland Statistics, 2006. Brodgar Software Package for Data Exploration, Univariate Analysis, Multivariate Analysis and Time Series Analysis, Vers. 2.5.2. Newburgh, UK.

Joiris, C.R., 1991. Spring distribution and ecological role of seabirds and marine mammals in the Weddell Sea, Antarctica. Polar Biology 11, 415-424.

Kerry, K.R., Clarke, J.R., Else, G.D., 1995. The foraging range of Adélie penguins at Bechervaise Island Mac Robertson Land Antarctica as determined by satellite telemetry. In: Dann, P., Norman, I., Reilly, R. (Eds.), The penguins: ecology and management. Second International Penguin Conference, Cowes, Victoria, Australia, August. Surrey Beatty, Chipping Norton, NSW, Australia, pp. 216-243. 
Kirkwood, R., Robertson, G., 1997. Seasonal change in the foraging ecology of emperor penguins on the Mawson Coast, Antarctica. Marine Ecology Progress Series 156, 205-223.

Kooyman, G.L., 2002. Evolutionary and ecological aspects of some Antarctic and sub-Antarctic penguin distributions. Oecologia 130, 485-495.

Lake, S.E., Burton, H.R., Hindell, M.A., 1997. Influence of time of day and month on Weddell seal haulout patterns at the Vestfold Hills, Antarctica. Polar Biology 18, 319-324.

McCullagh, P., Nelder, J.A., 1989. Generalized Linear Models, second ed. Chapman \& Hall, New York.

McMahon, C., Hindell, M., Dorr, T., Massom, R.A., 2002. Winter distribution and abundance of crabeater seals-off George V Land, East Antarctica. Antarctic Science 14, 128-133.

Orsi, A.H., Nowlin, W.D., Whitworth, T., 1993. On the circulation and stratification of the Weddell Gyre. Deep-Sea Research I 40, 169-203.

Pfaffling, A., Haas, C., Reid, J.E., 2007. A direct helicopter EM-sea ice thickness inversion, assessed with synthetic and field data. Geophysics 72, F127-F137.

Quinn, G.P., Keough, M.J., 2004. Experimental design and data analysis for biologists. Cambridge, UK.

R Development Core Team, 2006. R: A Language and Environment for Statistical Computing. R Foundation for Statistical Computing, Vienna.

Reijnders, P.J.H., Plötz, J., Zegers, J., Grafe, M., 1990. Breeding biology of Weddell seals (Leptonychotes weddellii) at Drescher Inlet, Riiser Larsen Ice Shelf, Antarctica. Polar Biology 10, 301-306.

Scripps Oceanographic Institution, 2006. WWW page, 〈http://topex. ucsd.edu/marine_topo/mar_topo.html $>$.

Siniff, D.B., 1991. An overview of the ecology of Antarctic seals. American Zoologist 31, 143-149.

Siniff, D.B., Cline, D.R., Erickson, A.W., 1970. Population densities of seals in the Weddell Sea, Antarctica in 1968. In: Holdgate, M.W. (Ed.), Antarctic Ecology, vol. 1. Academic Press, London, New York, pp. 377-397.

Smith, W.H.F., Sandwell, D.T., 1997. Global sea floor topography from satellite altimetry and ship depth soundings. Science 277, 1956-1962.

Southwell, C., 2005a. Optimising the timing of visual surveys of crabeater seal abundance: haulout behaviour as a consideration. Wildlife Research 32, 333-338.
Southwell, C., 2005b. Response behaviour of seals and penguins to helicopter surveys over the pack ice off East Antarctica. Antarctic Science 17, 328-334.

Southwell, C., Kerry, K., Ensor, P., Woehler, E.J., Rogers, T., 2003. The timing of pupping by pack-ice seals in East Antarctica. Polar Biology $26,648-652$.

Southwell, C.J., Kerry, K.R., Ensor, P.H., 2005. Predicting the distribution of crabeater seals Lobodon carcinophaga off East Antarctica during the breeding season. Marine Ecology Progress Series 299, 297-309.

Tynan, C.T., 1998. Ecological importance of the southern boundary of the Antarctic Circumpolar Current. Nature 392, 708-710.

Van Franeker, J.A., 1992. Top predators as indicators for ecosystem events in the confluence zone and marginal ice zone of the Weddell and Scotia seas, Antarctica, November 1988 to January 1989 (EPOS Leg 2). Polar Biology 12, 93-102.

Van Dam, R.P., Kooyman, G.L., 2003. Latitudinal distribution of penguins, seals and whales observed during a late autumn transect through the Ross Sea. Antarctic Science 16, 313-318.

Van Franeker, J.A., Bathmann, U.V., Mathot, S., 1997. Carbon fluxes to Antarctic top predators. Deep-Sea Research II 44, 435-455.

Weimerskirch, H., Inchausti, P., Guinet, C., Barbraud, C., 2003. Trends in bird and seal populations as indicators of a system shift in the Southern Ocean. Antarctic Science 15, 249-256.

Wiig, O., Derocher, A.E., 1999. Application of aerial survey methods to polar bears in the Barents Sea. In: Garner, G.W., Amstrup, S.C., Laake, J.L., Manly, B.F.J., McDonald, L.L., Robertson, D.G. (Eds.), Marine Mammal Survey and Assessment Methods. Balkema, Rotterdam Brookfield, pp. 27-36.

Woehler, E.J., 1993. The Distribution and Abundance of Antarctic and sub-Antarctic penguins. Scientific Committee on Antarctic Research (SCAR). Cambridge, England.

Woehler, E.J., 1997. Seabird abundance, biomass and prey consumption within Prydz Bay, Antarctica, 1980/1981-1992/1993. Polar Biology 17, 371-383.

Yaremchuk, M., Nechaev, D., Schröter, J., Fahrbach, E., 1998. A dynamically consistent analysis of circulation and transports in the southwestern Weddell Sea. Annales Geophysicae-Atmospheres, Hydrospheres and Space Sciences 16, 1024-1038. 